\title{
Prisão e Redenção: Fragmentos Estoicos para Pensar a Crítica Organizacional
}

\section{Prison and Redemption: Stoic Fragments to Help Thinking about Critical Theory of Organizations}

\author{
Ricardo Lebbos Favoreto ${ }^{1}$, Arnaldo José França Mazzei Nogueira ${ }^{1}$ \\ ${ }^{1}$ Pontifícia Universidade Católica de São Paulo, PUC-SP, Brasil. \\ Correspondência: Ricardo Lebbos Favoreto. Rua Monte Alegre, 984, Perdizes, CEP 05.014-901, São Paulo, SP, \\ Brasil. Telefone: +55 (11) 3124-9600. E-mail: ricardo.favoreto@ hotmail.com.
}

Recebido: 09 de janeiro de 2018 Aceito: 28 de setembro de 2018 Publicado: 28 de dezembro de 2018

DOI: http://dx.doi.org/10.21714/1679-18272018v16n1.p101-102

Esta obra está licenciada sob uma Licença Creative Commons Attribution 3.0.

\begin{abstract}
RESENHA
"Sêneca e o Estoicismo" é um livro radiante. Com uma escrita madura, Veyne exibe a virtuosa capacidade daqueles que conseguem se aproximar do leitor sem abrir mão da erudição que assinala o bom processo de pesquisa. Uma leitura que vale a pena, é certo. Agora, por que falar de Sêneca no âmbito dos estudos organizacionais? Como, especificamente, a visão de Veyne sobre Sêneca e o estoicismo contribui para pensarmos a crítica organizacional?

Cobrindo o período compreendido entre 1 e 63 d.C., o prólogo avança por praticamente toda a vida de Sêneca, que durou de 4 a.C. a 65 d.C. Poderia ter prosseguido até o fim. É em 63, no entanto, que se manifesta sua grande decepção e Sêneca opta pelo exílio interior. A partir desse momento, revela-se um Sêneca "realizado pela escrita", "um meditativo realizado em sua vida interior" (p. 215). Daí a significância de 63. Seus anos finais, de 63 a 65, são cobertos pelo epílogo. O capítulo intermediário, encerrando o bloco constituído pelas três seções fundamentais, dedica-se aos alicerces da filosofia estoica, conduzindo-se pelo recurso iterado a fragmentos da vida e do pensamento senecaniano. Leva, em vista disso, o mesmo título do livro, "Sêneca e o estoicismo". Após o epílogo, são ainda disponibilizadas ao leitor quatro pequenas seções suplementares que favorecem a assimilação do conteúdo do livro, assim como seu manuseio. As seções intituladas "notas" e "cronologias" contêm elementos criadores de cenários, capazes de transportar a mente do leitor para a época dos fatos relatados.
\end{abstract}

Quem nunca ouviu falar de Sêneca pode surpreender-se ao deparar com um homem que desenvolveu em si uma miríade no mínimo (pelo menos para os padrões de hoje) inusitada de personagens. Filósofo, político, conselheiro imperial, banqueiro: quem foi a maior celebridade estoica e como ela amoldou o estoicismo em seu pensamento? A resposta é perseguida ao longo do livro e, nessa jornada, Veyne passa por Sêneca, pelo estocismo (filosofia surgida três séculos antes de Sêneca) e pelo estoicismo em Sêneca. Dela, resgatam-se aqui, num movimento inopinado como a biografia de Sêneca, alguns elementos que podem ser aderidos à crítica organizacional.

Particularismo. A filosofia estoica prioriza o individual. O sábio interessa-se "por si mesmo, e o estoicismo, apesar de sua severidade, dirige-se antes de tudo ao indivíduo" (p. 118). Na modernidade, ideias como ordem pública e bem comum sobrepuseram-se ao ser humano, que passou a ser visto em termos de entidade humana. Integrado a uma estrutura funcionalmente estabelecida, o indivíduo moderno tornou-se um ator que se efetiva quando em prol de todos os demais, sendo, ao mesmo tempo e em sentido reverso, destinatário do conjunto constituído pela somatória da mesma atuação de cada ator. Nessa dinâmica, o indivíduo desvanece. Vemos emergidos o organismo durkheiniano, a burocracia weberiana, o sistema parsoniano - enfim, o peso do coletivo. A gravidade que liga o indivíduo ao mundo atinge-o, sob muitos aspectos, apenas indiretamente, pelo pertencimento comunitário. As medidas de triunfo atrelam-se, dessa forma, à organização, não ao indivíduo. Crescimento econômico do Estado? Por que não bem-estar individual? Fusões e aquisições podem resultar em aumento de participação de mercado, mas o que sobrevém aos trabalhadores? E aos consumidores, que se veem diante de oligopólios? Para o estoicismo, "a felicidade é individual ou não é; o que seria uma felicidade que nenhum indivíduo no mundo pudesse sentir?" (p. 118).

Entendimento. A retidão é um dos pilares do estoicismo. Não é, no entanto, no produto que se encontra a sabedoria, mas nos fundamentos seus. Embora a ação reta possa ser praticada por acaso, sua consistência é efeito do bem 
pensar. Reproduzindo Sêneca, Veyne registra: "não adianta um homem fazer o necessário, ele não o fará sempre, nem segundo uma regra uniforme, se ignorar por que cumpre agir assim" (p. 131). Animus, o estado de espírito: é o que importa para os estoicos. Na crítica sócio-filosófica, a díade constituída por esclarecimento, de um lado, e alienação, de outro, é uma representação clássica dessa dialética. Embora parte da crítica posicione-se incrédula quanto à possibilidade de esclarecimento, a alienação é elemento derivante do discurso crítico em geral, inclusive nos estudos organizacionais. Ao contrário do que pode parecer à primeira vista, os estoicos - alerta Veyne - não são moralistas; a moral estoica não é a da intenção, mas a da saúde mental. É pela via do esclarecimento (termo utilizado aqui apenas para fins de conexão das ideias), não pela do acaso nem do cumprimento da regra pela regra, que o indivíduo encontraria no bem-agir o objetivo maior da sapiência estoica, a felicidade.

Redenção. A alienação tende a ser concebida na crítica como um calabouço. Livrar-se dos grilhões que aprisionam o indivíduo no seu interior constitui tarefa árdua, senão ilusória. Consistem eles não apenas de amarras estruturais gregárias, como também, e sincronicamente, de amarras psíquicas. Não por acaso, a crítica habermasiana, por exemplo, ancora-se em Marx e também em Freud. O estoicismo é muito anterior à modernidade, elemento de referência na teoria crítica. Não são os mesmos, portanto, os motivos que ensejam a redenção estoica. A filosofia estoica visa a sabedoria, em princípio disponível a quem a almeje. Tanto no Sêneca autor quanto no Sêneca indivíduo, a redenção alcança a estremadura da vida humana - o ato de suicídio. "Morrer como sábio, uma vez que viver como sábio talvez não passe de utopia" (p. 156). A morte é forma de redenção e o suicídio, demonstração de força e disciplina intelectual. A redenção de Sêneca, para quem a morte é uma "porta sempre aberta" (p. 157), aponta para um resultado muito díspar do vislumbrado pela crítica (pelo menos por parte dela), mas testemunha a longevidade da angústia que causa a possibilidade, perpetuamente ponderada e quiçá meramente fictícia, de redenção.

Quando se pensa a crítica, uma multiplicidade de motes podem ser resgatados da filosofia estoica com desígnio cooperante. Nota-se, então, que, a despeito de variarem as peripécias históricas, muito daquilo que hoje incomoda a razão humana já afligia os antigos. Mesmo desconhecendo o positivismo (corrente filosófica surgida no século XIX), Sêneca, refletindo sobre a alma, recusa-se a admitir uma visão ("por demais positivista") conforme a qual "essa alma que se eleva como um sopro ou bolha de ar pode permanecer bloqueada" (p. 168). Sêneca, como firme estoico, mantém-se distante do platonismo, mas, ao mesmo tempo, não acolhe a submissão irrestrita de todas as coisas às leis físicas. Ora, o antipositivismo é característica pronunciada da crítica, inclusive a organizacional. Evidentemente, não se pretende com isso desqualificar a originalidade da crítica. Disparatado seria olvidar, por exemplo, a contemporaneidade de fenômenos como o capitalismo e a globalização. Todavia, esboça-se às vezes uma comedida impressão de que a inquietação manifestada pela crítica não tem por fundamento apenas fatos reais, como as patologias (inequívocas) da modernidade identificadas por Habermas, mas também o componente humano que, por sua vez, os fundamenta. É na humanidade que se encontram as confluências de pensamentos separados por milênios. Lendo "Sêneca e o estoicismo" em 2017, é quase inevitável não pensar na indissociável relação que há entre o ser humano e o mundo e, por consequência, na nossa inexorável sujeição a um eterno retorno, primeiro estoico, depois nietzschiano.

\section{Referência}

VEYNE, P. Sêneca e o Estoicismo. São Paulo, Brasil: Três Estrelas, 2015. 279 p. 